\title{
The Influence of Pop-up Advertising on Consumer Purchasing Behavior
}

\author{
A case study of social media users in Ghana
}

\author{
Le Wang \\ School of Management \\ Bohai University \\ Jinzhou China \\ lewang1982@163.com \\ Flora Ampiah \\ School of Management \\ Bohai University \\ Jinzhou China \\ flobaby16@gmail.com
}

\author{
Lei Xu \\ School of Management \\ Bohai University \\ Jinzhou China \\ passionlei@sina.com
}

\author{
Xiaoshu Wang \\ Internship and Employment Office \\ Bohai University \\ Jinzhou China \\ xiaoshu_1984@126.com
}

\begin{abstract}
Social media platforms such as Facebook, Twitter, MySpace, LinkedIn, and Youtube have attracted substantial number of users, many of whom spend several hours daily on these platforms. These platforms have therefore become fertile grounds for marketers/advertisers to target different types of customers. However, the impact of these ads has become more and more pervasive. The study therefore explores the influence of online advertising, especially popup ads on the purchase behavior of social media users. A sample of social media users who are familiar with these online ads were drawn from a public university in Ghana. The findings reveal that social media users perceive online ads, especially pop-up ads as intrusive and ineffective. Also the study establishes that pop-up ads have little impact on the purchase behavior of social media users since a negative attitude has been formed towards pop-up ads. Based on the findings of the study, it is recommended, among other things, that advertisers should design pop-up ads that are user friendly and less intrusive.
\end{abstract}

Keywords-online advertising; social media; pop-up ads; purchasing behavior; Ghana

\section{INTRODUCTION}

As a result of the proliferation of information and communication technologies, the internet has become an important medium for people to interact with each other in the cyber world. The ubiquitous nature of the internet has significantly changed the way daily activities are conducted by people in the $21^{\text {st }}$ century. Online browsing has become integral part of individuals, businesses and professional groups. On daily basis, several hours are spent to access contents on the internet. As indicated by Truong et al. (2010) more time is spent by many consumers on accessing online applications than television viewing. It is estimated that between 2000 and 2007 the number of people assessing the internet grew by over $244 \%$ worldwide (Internet World Stat).
The strategic importance of the internet and its significant growth over the years has given another avenue for marketers and businesses to advertise their products to the world. The rise in internet usage has seen equal rise in spending as far as online advertisement is concerned. Yaveroglu and Donthu (2008) explain that most marketers are now taking advantage of the internet revolution to make their products accessible to the world. The use of the internet as a media of advertisement has gained much popularity not only because internet has become ubiquitous but also because offers certain advantages compared with other forms of media. According to Chandon and Chtourou (2005), the most important feature that makes internet advertisement superior to other forms of advertisement is interactivity. Through this feature, the user is able to interact with the advertiser to find out more about the product/services. Other advantages of the internet such as flexibility, easy 24-hour access, and its global coverage are making the internet a preferred media for advertisement from most marketers.

Various varieties of online advertisements can be observed. These include floating ad, expanding ad, popups, wallpaper ads, trick banner, pop-under, among others. All these types of online ads are designed to catch the attention of the user. However, pop-up ads and all the other forms of online advertisements have taken a lot of pressure lately and this is because people believe that they are intrusive. Pop-up ads happen to be the -scapegoat" for all the people that hate advertising. Nevertheless, there is the need for an objective analysis of consumer perception of pop-up ads to understand whether they are bad or otherwise. The aim of this study is to explore and investigate the determinants of consumer behavior toward pop-up advertising, with two research objectives. First, the study examines the perceived intrusiveness of pop-up advertisement. Perceived intrusiveness means distracting, disturbing, forced, interfering, intrusive and obtrusive ( $\mathrm{Li}$ et al. 2002). Second the study examines the behaviour of 
social media users (Facebook, twitter, MySpace, Linkedln etc) towards pop-up advertisement.

The study has a number of theoretical and managerial implications. The results obtained from this research will help marketers make an informed decision in allocating funds for online/pop-up advertisements. It will also help in crafting customer/internet user friendly ways of designing pop-up ads. It will also help in determining to what extent pop-up ads affect customer purchase behavior.

\section{REVIEW OF LITERATURE}

In the view of Backshi and Gupta (2013) online advertisement involves delivering advertisements to Internet/online users via Web sites, e-mail, ad-supported software and Internet-enabled smart phones. The purpose of the internet adds is to inform users on the wide range of products and services on offer. Examples of online advertising include contextual ads on search engine results pages, banner ads, rich media ads, social network advertising, interstitial ads, online classified advertising, advertising networks and e-mail marketing, including email spam. The online advertisement may be classified into floating ad, expanding ad, pop-ups, wallpaper ads, trick banner, pop-under, among others (Backshi and Gupta, 2013). However, for the purposes of this study, pop-up ads are examined.

Pop up ad is a computer window which opens in front of the current one, displaying an advertisement, or entire webpage. Pop-ups are ads that appear in a separate window on top of the content a user is viewing. Usually, the pop-up window will not go away until the user actively closes it. Cho, et al (2001) has observed that pop-up ads have become common as a result of users' friendly attitude towards it. The authors observe that pop-up ads command higher purchase intention than standard banner ads. However, Edwards et al. (2002) explain that pop-up ads are perceived as irritating and annoying. The reason why people have negative attitudes towards pop-up is that they interrupt the web activities of users. For instance, in a study conducted by GartnerG2 (2002) it was observed that compared with other forms of online advertisement, popup adds are considered by consumers as the most irritating. From an advertiser's perspective, however, irritating ads may not always be bad. Some Internet advertisers use popup ads because of the in your face" impact they have (Dillabough, 2002). However, major online content/service providers such as EarthLink and America Online have recently responded to consumers' complaints about popups by employing new software that allows users to block pop-up ads (America Online," 2003). Some advertisers are also attempting to make pop-up ads less annoying. One strategy is to use them in situations where users are likely to be online for diversion or to avoid boredom rather than where they are focused on a specific goal. Another strategy to reduce annoyance may be to increase the value of popup ads. Edwards et al. (2002) found that when pop-up ads provided value to consumers, they were perceived as less irritating.

\section{A. Effectiveness of Online Advertisement}

Measuring the effectiveness of online advertisement is important for advertisers. Various methods have been designed to track the effectiveness of these ads. However, the methods employed in measuring the effectiveness of online advertisement are not significantly different from the ones used in conventional media. This is because according to Pavlou and Stewart (2000), the response of consumers towards online advertisement is similar to conventional media (radio, television, magazines, and newspapers). For instance attitude-based measurements used to determine online advertising effectiveness are similar to those applied in the conventional media: liking, attitude to the ad and attitude to the brand (Martin-Santana and Beerli-Palacio 2011). Lavrakas et al. (2010) state that traditional measurements such as unaided recall, aided recall, brand exposure brand image, purchase intention, propensity to purchase brand and actual brand purchases, are important in internet advertising effectiveness research, and current studies should routinely include such variables. Researchers who investigated online advertising effectiveness generally used either direct response measurements such as CTR or the more traditional brand measurements such as advertising recall, attitude toward the ad, or attitude toward the brand (Yaveroglu and Donthu, 2008). For the purposes of this study, purchase intentions are used to measure the effectiveness of online/pop-up ads.

\section{B. Social Media Advertisement}

According to Kaplan and Haenlein (2010, p. 61), social media is a group of internet based applications that build on the ideological and technological foundations of Web 2.0, and allow the creation and exchange of user generated content." Also, Hanafizadeh et al. (2012) define social network as a web applications allowing users to build personal web sites accessible to other users for exchanging content. For a website to be described as a social media network, it must meet certain requirements. It must contain user profiles, content, that permits users to connect with each other and post comments on each other's pages, and join virtual groups based on common interests such as fashion or politics (Lenhart \& Madden, 2007; Winder, 2007). For instance facebook, twitter, istagram, myspace, Linkedln etc can be described as social media platform. Social media has become an effective tool in the hands of discerning advertisers. These sites are being used by advertisers to promote and sell different kinds of products and services. It therefore offers businesses the opportunity to present advertised offers which spread virally as people accept" the offer acting as brand advocates for your brand by pushing this to their friends. With the ever increasing number of customers on these social media platforms, social media is projected to ramp up its revenue generating activities (Bakshi and Gupta, 2013)

\section{RESEARCH DESIGN AND METHODOLOGY}

\section{A. Research Design}

The study adopted a quantitative research methodology. Surveys were conducted amongst 120 active social media users (Facebook, Twitter, MySpace etc) in Ghana. The study employs attitude-based measurements to determine online advertising effectiveness. The items used in measuring the effectiveness of pop-up ads was coded on a five point-Likert scale, ranging from strongly disagree (1) to strongly agree (5). The responses received were 
descriptively analyzed using Statistical Package for the Social Sciences (SPSS).

\section{B. Data}

Surveys were conducted amongst 120 social media users in a public university in Ghana. This was done between July and August 2014. A structured questionnaire was developed to solicit responses from regarding their perception of online, especially pop-up ads.

\section{Profile of Respondents}

The characteristics of the participants' population are presented in TABLE I. The result reveals that there is a balance between male and female participants. Also majority of respondents are between the ages of 25-34 years. Most of the respondents have up to a first degree and visit social media platforms at least once a day. In addition, majority of the participants have had experience with social media platforms for between three to six years.

TABLE I. PROFILE OF PARTICIPANTS (120)

\begin{tabular}{|l|l|l|l|}
\hline Variable & Classification & No. & $\begin{array}{l}\text { Percent } \\
(\mathbf{\% )}\end{array}$ \\
\hline \multirow{2}{*}{ Gender } & Male & 62 & 51.7 \\
& Female & 58 & 48.3 \\
\hline \multirow{4}{*}{ Age } & $20-24$ & 32 & 26.7 \\
& $25-34$ & 36 & 30.0 \\
& $35-44$ & 27 & 22.5 \\
& $45-54$ & 18 & 15.0 \\
\hline \multirow{2}{*}{ Education } & $55-64$ & 7 & 5.8 \\
\hline Frequency of & Bachelor's degree & 98 & 81.7 \\
internet access & Higher University degree & 22 & 18.3 \\
\hline \multirow{2}{*}{ Experience } & At least once a day & 108 & 90.0 \\
with social & Less than 6 months a week & 12 & 10.0 \\
media & Between 6 months and 1 years & 4 & 3.3 \\
platforms & More than 1 year to 3 years & 29 & 16.7 \\
& More than 3 years to 6 years & 52 & 43.2 \\
& More than 6 years & 15 & 12.5 \\
\hline
\end{tabular}

\section{ANALYSIS AND DISCUSSION OF RESULT}

\section{A. Perception of social media users towards of Pop-Up Advertising}

An individual's perception of online advertisement plays a major role in whether or not they are motivated to partake in consumption activities (Mady 2011). The study sought to examine how social media users in Ghana perceive pop-up ads on the various social media platforms. For Perceived intrusiveness of pop-up advertisement was measured using six key items. These include; interference, disturbance, obstruction, intrusion, annoyance and forcefulness. These items were measured on a five-point likert scale ranging from 1 (strongly disagree) to 5 (Strongly agree). The higher the mean score, the more intrusive users view pop-up ads. The responses are captured in TABLE II.

The result shows that respondents unanimously agree that pop-up ads are obstructive. The result is in agreement with Edwards et al. (2002) who explain that pop-up ads are perceived as irritating and annoying. The reason why described as intrusive is that most often it interrupts the online activities of users. Also, a study conducted by
Gartner G2 (2002) confirms the perception of the participants that pop-up ads are considered by online users as the most intrusive form on advertisement.

TABLE II. PERCEIVED INTRUSIVENESS OF POP-UP ADS

\begin{tabular}{|l|l|l|l|}
\hline Items & Mean & S.D & Std. Error \\
\hline It is Interfering & 4.05 & 0.553 & 0.054 \\
It is disturbing & 3.85 & 0.608 & 0.059 \\
It is obstructive & 4.38 & 0.489 & 0.048 \\
It is Intrusive & 4.46 & 0.573 & 0.056 \\
I feel forced & 3.19 & 0.738 & 0.072 \\
It is annoying & 4.19 & 0.738 & 0.072 \\
Overall Mean & 4.02 & & \\
\hline
\end{tabular}

KEY: SD — STRONGLY DISAGREES; D-DiSAGREE; NAD - NEITHER AgreE NOR DISAGREE; A-AGREE; SA-STRONGLY AGREE: SCALE (MEAN) $0-2.5=$ LOW; $2.51-3.5=$ AVERAGE AND 3.51 AND ABOVE $=$ HIGH.

\section{B. Social Media Membership of Participants}

The researcher sought to examine the membership of participants on the various social media platforms. Unsurprisingly, the result reveals that among the various social media platforms, Facebook is the most popular among participants. For instance, from Fig .2, it can be observed that $95.8 \%$ of the respondents are members of the Facebook platform. This is followed by Twitter $(40.5 \%)$, Linkedln (12.1\%), MySpace (8.7\%) and others (4.9\%). The result clearly shows that Ghanaian social media users are more used to Facebook than any other social media platform.

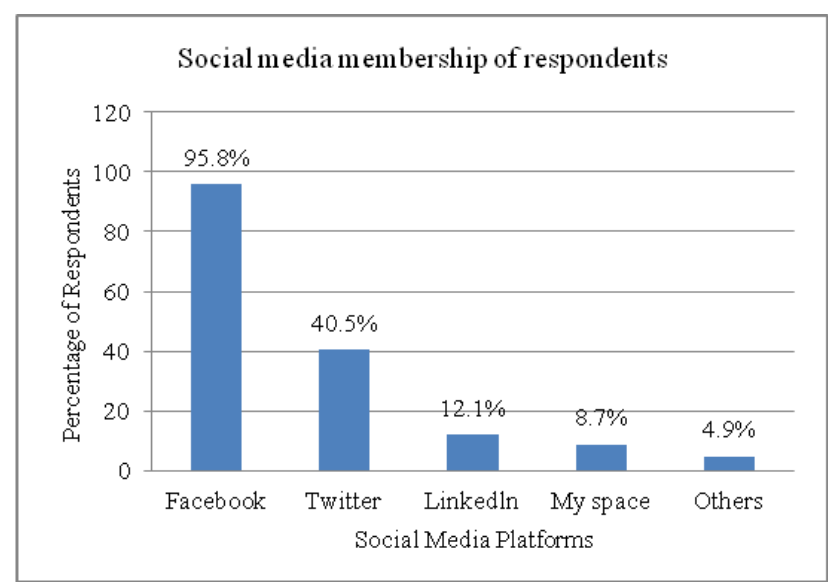

Figure 1. Social media membership of participants.

\section{The impact of Pop-up advertising on the purchase behavior of respondents}

The respondents were asked to indicate the extent to which pop-up ads on the social media influence their purchase behavior. The result indicates that only $2.5 \%$ are highly influenced by these ads. Also, $10.2 \%$ of the respondents indicated that they are somewhat influenced by these pop-up ads. However, over $64 \%$ of the respondents stated that they are not influenced by these pop-up ads. This means that they either ignore these ads as unimportant or do not give them the attention they deserve. 


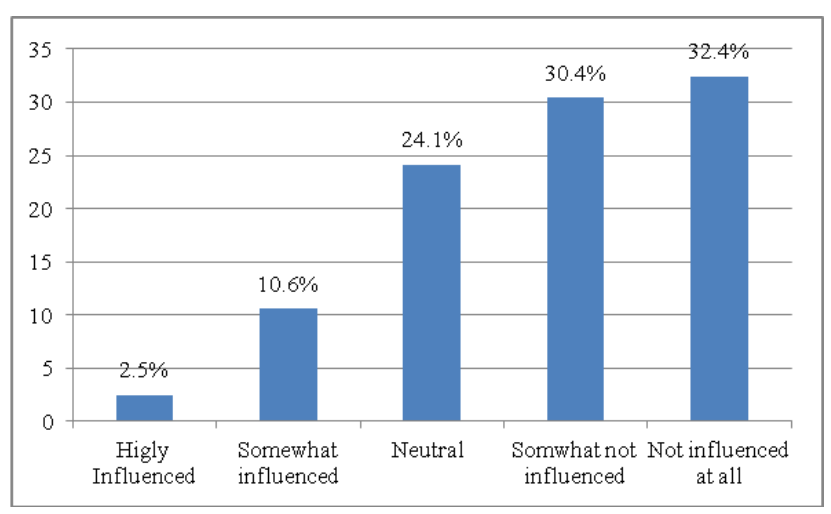

Figure 2. The extent to which pop-up ads influence the purchase decisions of Respondents

\section{Attitudes toward pop-up advertising}

The online advertisement attitude of consumers was measured on a using four items. These items were measured using a five-point liker scale ranging from 1(Strongly disagree) to 5 (strongly disagree). The items were overall, I consider pop-up advertising a good thing “; overall, I like pop-up advertising; I consider pop-up advertising very essential' "; and I would describe my overall attitude toward pop-up advertising very favorably." The mean of the four items served as the index of attitudes toward advertising. The higher the mean score, the more positive attitude users of social media holds toward pop-up advertising. The result is presented in Table 3 . The result indicates that the overall mean of the item is 2.55 indicating that the attitude of respondents towards pop-up advertising is not positive. This perceived negative attitude towards pop-up ads may be as a result of its intrusive nature.

TABLE III. ATtITUDE OF RESPONDENTS TOWARDS POP-UP ADVERTISING

\begin{tabular}{|l|l|l|}
\hline Items & Mean & S.D \\
\hline I consider pop-up advertising a good thing & $\mathbf{2 . 5 4}$ & $\mathbf{0 . 9 5 3}$ \\
I like pop-up advertising & $\mathbf{2 . 8 5}$ & $\mathbf{0 . 7 0 8}$ \\
consider pop-up advertising very essential & $\mathbf{2 . 3 8}$ & $\mathbf{0 . 8 9 1}$ \\
$\begin{array}{l}\text { I would describe my overall attitude toward } \\
\text { pop-up advertising is very favorably }\end{array}$ & $\mathbf{2 . 4 6}$ & $\mathbf{1 . 0 3 2}$ \\
Overall Mean & $\mathbf{2 . 5 5}$ & \\
\hline
\end{tabular}

Key: SD—strongly disagrees; D—Disagree; NAD —-Neither Agree nor disagree; A-Agree; SA-strongly agree: scale (mean) $0-2.5=$ low; $2.51-3.5=$ Average and 3.51 and above $=$ High .

Source: Field Data, July, 2014

\section{CONCLUSION AND IMPLICATIONS}

The study reveals that users of social media have negative attitude towards pop-up ads mainly because of its intrusive/obstructive nature. As a result, these ads are not positively influencing their purchase behavior. In other words, the products/services advertised through pop-up ads do not appeal to these users. Based on the result obtained from the study, it can be concluded that pop-up ads are not effective in influencing the purchase behavior of social media users in Ghana. The main practical implications of this study centre on the design of online advertisements. Using an advertising format that is perceived by online users as obstructive has the potential of being ineffective. Thus, advertisers and managers should therefore pay particular attention to pop-up ads that are user friendly and less obstructive. In order for pop-up ads to be useful for advertisers/marketers its effectiveness must be improved. To achieve this there is the need for pop-up ads to be designed in such a way that it provides valuable information to online users.

As in most empirical research, this study was not without limitations. First, the conclusions drawn from this study are based on the perception of respondents. The researcher was unable to independently verify their claims. Second, the study was conducted by sampling a cross section of university students in Ghana. It is recommended that this study be replicated in other parts of Africa and other continents to determine whether regional variations exist in the above findings. Also, the study was limited to only social media users only. It is recommended that future studies should replicate this study by considering other forms of internet users.

\section{REFERENCES}

[1] G. Bakshi, and K. Gupta, -nline Advertising and its impact on customer buying behaviour", IJRFM, vol.1 No3, 2013, pp. 21-30.

[2] P.Hanafizadeh, A. Z. Ravasan, A.Nabavi, and M. Mehrabioun, A Literature Review on the Business Impacts of Social Network Sites", International Journal of Virtual Communities and Social Networking, vol.4 No1, 2012,pp. 46-60.

[3] A. M.Kaplan, and H.Michae, Users of the World, Unite! The Challenges and Opportunities of Social Media", Business Horizons vol.53, 2010, pp. 59-68.

[4] J. D. Martin-Santana. and A. Beerli-Palacio, The effectiveness of web ads: rectangle vs contextual banners", Online Information Review vol. 36 No. 3, 2012, pp. 420-441.

[5] Y. Truong, R. McColl, and P. Kitchen, Practitioners ' perceptions of advertising strategies for digital media", International Journal of Advertising, vol. 29 No. 5, 2010, pp. 709-25.

[6] I. Yaveroglu, and N. Donthu, Advertising repetition and placement issues in on-line environments", Journal of Advertising, vol. 37 No. 2, 2008, pp. 31-43

[7] R. Samson, M. Mehta, A. Chandani, Impact of Online Digital Communication on Customer Buying Decision", Procedia Economics and Finance, vol. 11, 2014, pp. 872-880.

[8] M. Ding, J. Eliashberg, Innovation and Marketing in the Pharmaceutical Industry: Emerging Practices, Research, and Policies", New York: Springer, 2014.

[9] R. Breuer, M. Brettel, Short and Long-term Effects of Online Advertising: Differences between New and Existing Customers", Journal of Interactive Marketing, vol.26, Issue 3, Aug 2012, pp. 155-166.

[10] C. Chang, A. Tseng, The post-purchase communication strategies for supporting online impulse buying", Computers in Human Behavior, vol. 39, Oct 2014, pp. 393-403.

[11] D. Duroy, P. Gorse, M. Lejoyeux, Characteristics of online compulsive buying in Parisian students", Addictive Behaviors, vol. 39, Issue 12, Dec2014, pp.1827-1830.

[12] C. Kim, S. Park, K. Kwon, W. Chang, How to select search keywords for online advertising depending on consumer involvement: An empirical investigation", Expert Systems with Applications, vol.39, Issue 1, Jan 2012, pp. 594-610. 